\title{
Genetic Structure in Native Populations of Grape Phylloxera (Homoptera: Phylloxeridae)
}

\author{
HONG LIN, ${ }^{1}$ DOUGLAS A. DOWNIE, ${ }^{2}$ M. ANDREW WALKER, ${ }^{1}$ JEFFREY GRANETT, ${ }^{2}$ AND \\ GREG ENGLISH-LOEB ${ }^{3}$
}

\begin{abstract}
Ann. Entomol. Soc. Am. 92(3): 376-381 (1999)
ABSTRACT Random amplified polymorphic DNA (RAPD) markers were used to study genetic structure and diversity in native grape phylloxera populations growing on Vitis arizonica Englemann in central Arizona and on V. riparia Michaux in New York. RAPD data from the Arizona collections were clustered into 3 subpopulations, whereas data from the New York collections were not clustered, which reflected topographic features and the distribution of the sampled vines. Similarity coefficients of the 2 collection areas had similar ranges $(0.89-1.0)$. The similarity coefficient between the Arizona and New York collections was 0.62 . Analyses of molecular variance were used to partition the variance in genetic distances, and confirmed the results of the dendrogram clustering. The clustering of the Arizona populations is likely the result of gene flow restriction caused by geographic isolation. Greater diversity was expected among the Arizona populations. That diversity levels were similar suggests that other factors, such as inbreeding or past population history, must play a role in the relatively low level of diversity found in Arizona.
\end{abstract}

KEY WORDS Daktulosphaira vitifoliae, Vitis, random amplified polymorphic DNA, genetic diversity

THE GRAPE PHYLLOXERA, Daktulosphaira vitifoliae (Fitch), is endemic to North and Central America and has been introduced throughout the world's grapegrowing regions. Phylloxera-resistant rootstocks were developed $\approx 100$ yr ago and have effectively controlled the root damage caused by this pest. One of these rootstocks, AXR\#1, was extensively used during the rapid expansion of the California grape acreage in the 1960 s and 1970s. This rootstock is a Vitis vinifera $\mathrm{L}$. $\mathrm{x}$ $V$. rupestris Scheele hybrid, and although it had a history of failure to phylloxera in Europe and South Africa early in this century, it was considered to be adequately resistant in California vineyards. By the early 1980s, a strain of phylloxera capable of killing vines grafted on AXR\#1 was identified in several California vineyards (Granett et al. 1985). Differential performance in bioassays using excised root pieces from various rootstocks has resulted in the identification of many other phylloxera strains (De Benedictis et al. 1996).

These findings stimulated a molecular study (Fong et al. 1995) using random amplified polymorphic DNA (RAPD) to examine the genetic diversity of grape phylloxera in California vineyards. Genetic similarity coefficients derived from RAPD banding patterns of 13 clones sampled from central California to southern Oregon varied from 0.747 to 1.0 . This result was un-

\footnotetext{
${ }^{1}$ Department of Viticulture and Enology, University of California, 1 Shields Avenue, Davis, CA 95616-8749.

${ }^{2}$ Department of Entomology, University of California, 1 Shields Avenue, Davis, CA 95616.

${ }^{3}$ New York State Agricultural Experiment Station, Cornell University, Geneva, NY 14456.
}

expected given the assumption that the observed diversity was the result of evolution over $\approx 100 \mathrm{yr}$ in a lineage reproducing by apomictic parthenogenesis, and that phylloxera were imported relatively few times. Further, the biotypes and strains defined by their feeding behavior on root bioassays did not cluster together as expected; they were genetically diverse (Fong et al. 1995). Studies of genetic variation within and among native populations of grape phylloxera may help to clarify the basis of the genetic diversity in introduced populations and help to answer fundamental questions about the evolution and adaptation of phylloxera to grape rootstocks.

Grape phylloxera are highly specialized members of the Aphidoidea which feed on leaves and roots of grape, Vitis spp. The complex life cycle includes apomictic parthenogenetic generations on the roots or in leaf galls with the potential to shift between feeding sites as the season progresses. After a variable number of generations on roots, alate sexuparae disperse and produce sexual morphs (males and females) that lack wings or mouthparts. Following mating, female sexuales lay a single diapausing egg (Davidson and Nougaret 1921). It is thought that only the asexual root feeding portion of the life cycle exists in California viticultural regions (Davidson and Nougaret 1921). In the U.S. Southwest, current evidence indicates that only the leaf galling portion of the life cycle exists. Alate forms have not been found and sexuales are produced within leaf galls by apterous parthenogenetic females. The lack of wings and mouthparts in southwestern sexuales suggest that mating must occur near the hatch site (Downie and Granett 1998). 
Vitis is a temperate and subtropical taxon of deciduous, dioecious vines found commonly in disturbed areas, riparian habitats, and oak woodlands. In the southwestern United States, grapes are found in mountain canyons and ravines at $\approx 1,200-1,800 \mathrm{~m}$ associated with oak, ponderosa pine, and willow (unpublished data). Suitable grape habitat is fragmented by intervening expanses of desert. In New York and elsewhere in the eastern United States, grapes are more continuously distributed. This continuous distribution of the host plant and presence of alates in eastern grape phylloxera populations may enhance movement among vines (Hawthorne and Dennehy 1991).

The objective of this study was to examine the genetic structure and genetic diversity present in native grape phylloxera at contrasting levels of population structure. Small, closed populations isolated from each other, as in the Southwest, should lead to genetic divergence among, but homogeneity within, populations. If neutral regions of the genome are surveyed, the level of divergence among such populations should correspond to the duration of their isolation (Nei 1987). Larger, open populations, as in New York, should lead to the erosion of genetic structure through gene flow and greater diversity because of higher levels of outcrossing. The potential for genetic structuring to occur at the level of individual vines exists in all grape phylloxera populations because of their sedentary nature and extreme host specificity (Edmunds and Alstad 1978). Herein, we refer to phylloxera on individual vines as colonies, not to be confused with clones, which represent the parthenogenetic descendants of a single female.

We used random amplified polymorphic DNA (RAPD) markers (Williams et al. 1990) to examine genetic structure in these phylloxera collections. RAPDs have been used to study genetic diversity (Kambhampati et al. 1992, Rui and Gerald 1996) and population genetic structure (Huff et al. 1993, Nolan et al. 1996), and to distinguish clones and biotypes of aphids (Black et al. 1992, Cenis et al. 1993). One needs only small amounts of biological sample material, and RAPDs are technically simple and efficient in detecting polymorphisms.

\section{Materials and Methods}

Sampling. In August 1995, phylloxera were collected from V. arizonica Engelmann vines at 3 sites in north central Arizona. Two of these sites (Lynx Creek and Bradshaw) were located on the opposite sides of a mountain at the edge of the Bradshaw Mountains and were separated by $\approx 20 \mathrm{~km}$., whereas the $3 \mathrm{rd}$ (Oak Creek) was located $\approx 80 \mathrm{~km}$. to the northeast of the Lynx Creek site and separated from it by desert and the Mingus Mountains. Grapes were not detected in the intervening areas. All sites are located between 1,400 and $1,700 \mathrm{~m}$ altitude.

Within each Arizona site, 3 vines with phylloxera leaf galls were located. The distance separating sampled vines within sites ranged from $\approx 50 \mathrm{~m}$ to $4 \mathrm{~km}$.
This represented a significant sampling of the infested vines in these sites. An extensive survey conducted in 1996 of these sites for the presence or absence of phylloxera-infested vines resulted in the following ratios: Oak Creek, 9/28; Lynx Creek, 7/26; Bradshaw, 3/35 (D.A.D. and J.G., unpublished data). A random sample of 6 galled shoots was collected from each of the 3 vines. The shoots were placed in plastic bags and kept cool until taken to the laboratory.

In July 1995, phylloxera were collected from $6 \mathrm{~V}$. riparia Michaux vines near Geneva, NY. Vitis riparia grows abundantly around Geneva, and vines are scattered throughout town near waterways and on landscape plantings. Vines A and B were $\approx 60 \mathrm{~m}$ apart at the north end of Geneva on Carter Road, vine C was 1.3 $\mathrm{km}$ south on Carter Road, vine D was on Highway 14 $0.5 \mathrm{~km}$ south of the intersection with Highway 20, vine E was $12 \mathrm{~km}$ south of vine D on Highway 14, and vine F was on Preemption Road, $1.6 \mathrm{~km}$ west of vine C. Six galled shoots from the 6 sampled vines were placed in separate plastic bags and kept cool until taken to the laboratory.

Samples for DNA analysis were obtained from galls on collected shoots. Eggs were placed on filter paper in 5-cm petri dishes for DNA extraction. Six galls were sampled from each of the New York vines for a total of 36 DNA samples ( 6 samples $\times 6$ vines). Four galls were randomly chosen from the 3 vines of each Arizona site for a total of 36 DNA samples (4 samples $\times$ 3 vines $\times 3$ sites). Because galls are initiated and generally inhabited by a single parthenogenetic individual (Davidson and Nougaret 1921, Downie and Granett 1998), it is likely that all eggs within a gall are genetically identical (barring mutation). We tested this by running separate RAPD reactions on single eggs subsampled from individual galls to confirm the genetic uniformity within a gall.

DNA Extraction. DNA samples were first extracted from each of 20 eggs within 3 galls to verify genetic identity. The RAPD results confirmed asexual clonal reproduction and allowed the use of bulked eggs from within a gall as a sample unit (Lin and Walker 1996). Second, DNA was extracted to examine genetic differences among vines and sites. About 20-50 eggs were collected from each gall, washed once with sterile water, then transferred to a glass microgrinder (Radnoti Glass, Arcadia, CA). DNA was extracted according to the procedure described previously (Lin and Walker 1996). DNA concentrations were determined by measuring $\mathrm{OD}_{260}$ and were adjusted to final concentration of $10 \mathrm{ng} / \mu \mathrm{l}$ for polymerase chain reaction (PCR) analysis.

PCR Amplification. Each 20 ( $\mu$ l of PCR reaction mixture contained $2 \mu \mathrm{l}$ of $10 \times$ buffer $(100 \mathrm{mM}$ Tris"HCl, pH 9.0, $500 \mathrm{mM} \mathrm{KCl}, 1 \%$ Triton X-100) (Promega, Madison, WI), 0.5U of Taq polymerase (Promega), $20 \mathrm{ng}$ DNA with $2 \mathrm{mM} \mathrm{MgCl} 2,0.2 \mathrm{mM}$ of dNTPs (Boehringer, Mannheim, Germany), 0.5 umole primer (Operon, Alameda, CA) at final concentration, according to the protocol described by Williams et al. (1990). PCR reactions were performed in a PTC-100 thermal controller (MJ Research, Watertown, MA) 
preheated to $94^{\circ} \mathrm{C}$ using the following cycling program: 4 cycles of $1 \mathrm{~min}$ at $94^{\circ} \mathrm{C}, 1.5 \mathrm{~min}$ at $37^{\circ} \mathrm{C}$ and 2 min at $72^{\circ} \mathrm{C}$; followed by 30 cycles of $0.5 \mathrm{~min}$ at $94^{\circ} \mathrm{C}$, $0.5 \mathrm{~min}$ at $37^{\circ} \mathrm{C}$ and $1 \mathrm{~min}$ at $72^{\circ} \mathrm{C}$. Operon primers OPG-2 (5'-GGCACTGAGG-3'), OPG-5 (5'-GTGAGACGGA-3'), OPG-7 (5'-GAACCTGCGG-3'), OPG-8 (5'-TCACGTCCAC-3'), OPG-9 (5'-CTGACGTCAC-3'), OPG-11 (5'-TGCCCGTCGT-3'), OPG-12 (5'-CAGCTCACGA-3'), OPG-13 (5'CTCTCCGCCA-3'), OPG-16 (5'-AGCGTCCTCC$\left.3^{\prime}\right)$, OPG-17 (5'-ACGACCGACA-3'), OPG-18 (5'GGCTCATGTG- $\left.3^{\prime}\right)$, and OPA-10 (5'GTGATCGCAG- $3^{\prime}$ ) were used. Amplified products were separated on $1.5 \%$ agarose gels and viewed under UV light after ethidium bromide staining.

Data Analysis. All RAPD markers were scored based on presence or absence of a band. These binary data were used to construct a rectangular data matrix, which was then converted into a similarity matrix using the simple matching coefficient of resemblance (Sneath and Sokal 1973). A dendrogram of genetic distances among each phylloxera collection site was constructed from the similarity matrix using the unweighted pair-group method (unweighted pair-group method with arithmetic average) (Sneath and Sokal 1973). Analysis was performed with NTSYS-PC software (Version 2.0, Exeter Software, Setauket, NY).

The genetic structure of the populations was investigated with analysis of molecular variance (AMOVA) (Excoffier et al. 1992). This analysis detects hierarchical structuring. Because the sampling structures were different, AMOVA was performed for Arizona and New York separately. The binary data matrices were first converted to Euclidean distance matrices (Huff et al. 1993), and AMOVA was performed using these separate data sets (Excoffier et al. 1992). This hierarchical analysis partitions the total variance into among individuals within colonies, among colonies within sites (New York), and among sites components (Arizona). The variance components were tested statistically using the nonparametric permutation approach described in Excoffier et al. (1992).

\section{Results}

Twenty RAPD primers were tested to detect polymorphism among individuals within single galls. No polymorphisms were found within the galls (results not shown), suggesting that individuals from the same gall are derived from a single parthenogenetic individual. Based on the test previously described, 12 primers that had successfully and reproducibly amplified in PCR were chosen to examine the genetic structure of phylloxera populations.

On average, 9 scorable amplified fragments were generated by each primer, ranging in size from 0.20 to $2.5 \mathrm{~kb}$. In total, 108 bands were scored from the 12 primers. Among them, 16 polymorphic bands (14.5\%) were found in Arizona populations, and 18 polymorphic bands (15.5\%) were recorded among the New York populations.

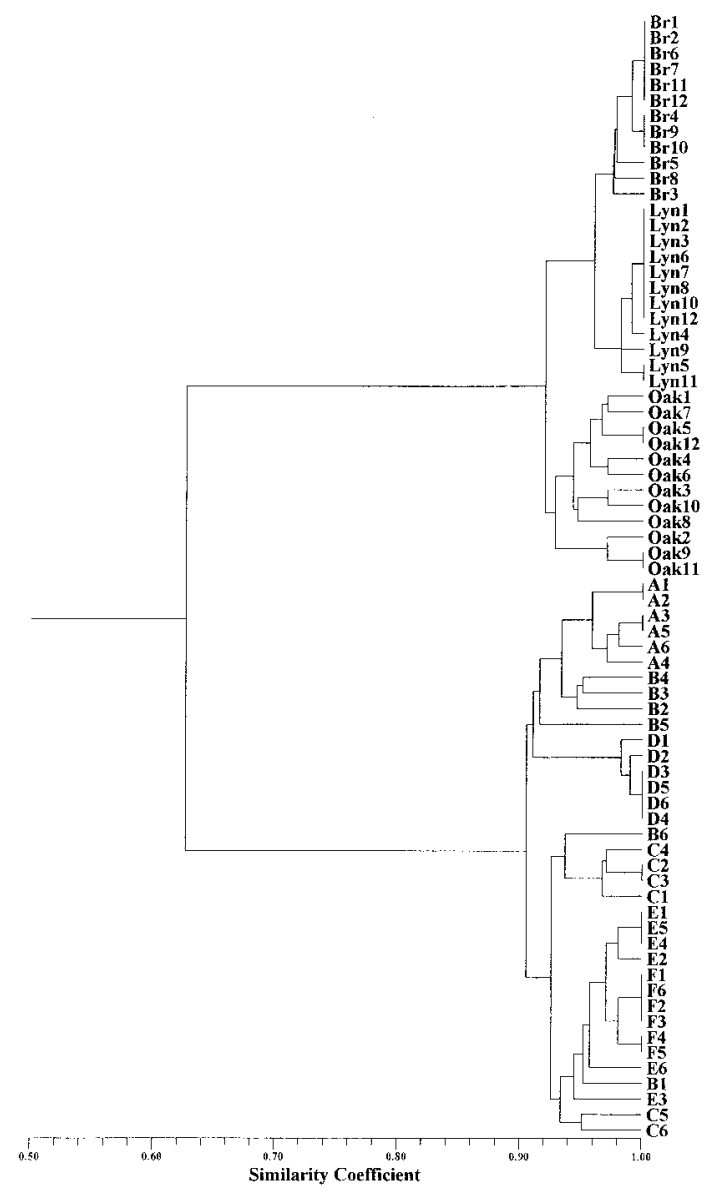

Fig. 1. Dendrogram constructed from cluster analysis with unweighted pair-group method and with arithmetic average method, presenting the genetic similarity among 36 phylloxera samples from Arizona and 36 from New York. The Arizona samples consisted of eggs from 4 leaf galls collected on $3 \mathrm{~V}$. arizonica vines at 3 locations (Br, Bradshaw Mountains; Lyn, Lynx Creek; and Oak, Oak Creek). The New York samples consisted of eggs from 6 galls collected on single $V$. riparia vines at 6 locations (labeled A through F) over a 14 km north-south transect across Geneva, NY.

The range in coefficients derived from the similarity matrices were similar in both collections $(0.9-1.00)$. The dendrogram constructed from the genetic similarities within and among the Arizona populations shows that the samples within Arizona collection sites are clustered (Fig. 1). The degree of similarity within each site is higher than that among sites (range of similarity coefficients within sites $0.92-1.0$, among sites 0.91-0.97). No overlap among sites was observed, suggesting that gene flow between these sites probably has not occurred recently.

The dendrogram generated from the New York data displayed a more random distribution of phylloxera samples relative to geographic proximity, although there is some indication that samples from within vines are more closely related than are those among vines 
Table 1. Analysis of molecular variance (AMOVA) performed separately for 2 native phylloxera collections, 36 samples from Arizona and 36 samples from New York, using 12 RAPD primers

\begin{tabular}{|c|c|c|c|c|c|c|}
\hline Source of variance & $\mathrm{df}$ & $\begin{array}{c}\text { Sum of } \\
\text { squared } \\
\text { deviation }\end{array}$ & $\begin{array}{c}\text { Mean } \\
\text { squared } \\
\text { deviation }\end{array}$ & $\begin{array}{c}\text { Variance } \\
\text { component }\end{array}$ & $\begin{array}{l}\text { Percentage } \\
\text { of variance }{ }^{a}\end{array}$ & $P^{b}$ \\
\hline \multicolumn{7}{|l|}{ Arizona } \\
\hline Among sites & 2 & 66.77 & 33.38 & 2.548 & 73.39 & $<0.001$ \\
\hline Among colonies within sites & 6 & 8.82 & 1.47 & 0.237 & 6.86 & $<0.001$ \\
\hline Samples within colonies & 27 & 22.62 & 0.84 & 0.759 & 20.41 & $<0.001$ \\
\hline \multicolumn{7}{|l|}{ New York } \\
\hline Among colonies & 5 & 84.81 & 16.96 & 2.525 & 58.15 & $<0.001$ \\
\hline Samples within colonies & 30 & 54.50 & 1.82 & 1.827 & 41.85 & $<0.001$ \\
\hline
\end{tabular}

The Arizona samples were from 3 sites (Bradshaw, Oak Creek, and Lynx), within which 3 vines were chosen with 4 leaf gall samples chosen from each vine. The New York samples were taken from 6 vines, with 6 gall samples collected from each vine.

${ }^{a}$ Percentage of total variance contributed by each component.

${ }^{b}$ Probability estimate of having a larger variance component by chance alone.

(Fig. 1). The proportion of distinct RAPD profiles (those with no similarity coefficients $=1$ ) was greater in New York $(24 / 36=0.67)$ than in Arizona $(19 / 36=$ $0.53)$ and was greater in Oak Creek $(10 / 12=0.83)$ than in the other 2 Arizona sites $(5 / 12=0.42$ and $4 / 12=0.33)$. Phylloxera from the 2 states were very different with a similarity coefficient of 0.62 between the Arizona and New York populations (Fig. 1).

Hierarchical analysis of genetic structure from Arizona populations using AMOVA found highly significant $(P<0.001)$ genetic differences among sites, among colonies within sites, and among individuals within colonies (Table 1). The partitioning of the total variance indicated that diversity in the Arizona collections was most attributable to differences among sites $(73.39 \%, P<0.001)$, whereas $6.86 \%$ was caused by differences among colonies within sites $(P<0.001)$, and $20.41 \%$ by differences within a colony $(P<0.001)$. AMOVA calculations for the New York collections found that $58.15 \%$ of the diversity was attributable to differences among colonies $(P<0.001)$ and $41.85 \%$ to differences within colonies $(P<0.001)$.

\section{Discussion}

Two regions with potentially different population structures and life histories were chosen to examine genetic diversity in native grape phylloxera. The Arizona sites are geographically isolated from each other and lack alate migrants; the New York sites are relatively connected through a contiguous distribution of host plants and have alate migrants. The isolation and distance separating populations in Arizona should lead to a greater degree of genetic divergence among these sites. The frequency of infested vines is lower in the southwestern than in the eastern United States (suggesting that population sizes are smaller (D.A.D. and J.G., unpublished data). Small effective population sizes and the absence of dispersal of sexuales by winged migrants suggest that genetic drift and inbreeding could act to enhance the divergence among these populations while maintaining low levels of variation within populations. In New York, sites are not only connected to each other through a contiguous host plant distribution but are connected to popula- tions of grape phylloxera outside the sampling area. This could lead to gene flow among sampled vines as well as influx from outside the sampling area, preventing structuring and increasing diversity. Our results largely confirmed these expectations.

The dendrogram depicting the relationships among the New York samples displayed a less clearly clustered arrangement than the dendrogram from Arizona samples (Fig. 1). In most cases, phylloxera collected from a given vine in New York were most similar to each other, but there were many examples of one or more samples being much more closely related to more distant vines. The differences seen could have been because of greater movement through winged migrants as well as a higher degree of sexual recombination than common in Arizona. The clear structuring evident in Arizona supports the interpretation that geographic barriers have restricted gene flow among populations. A question of interest is how long have these populations been isolated. The overall magnitude of the similarity coefficients in Arizona was similar to those in New York where geographic barriers are not present. This at least suggests that the time of separation may be on an ecological time scale (decades to centuries), although we cannot date coalescent events from RAPD data. Factors such as inbreeding, a bottleneck that severely depleted genetic variance, or an origin from a founder event could produce the observed pattern even if isolation had been in place for a considerable time.

RAPD banding patterns were quite different between the Arizona and New York collections (Figs. 2 and 3 ), and led to a relatively low similarity coefficient (0.62) between the 2 regions, indicating that these phylloxera populations are genetically distinct (Fig. 1 ). This result likely reflects the large geographic distance separating these populations, host selection, and the different abiotic conditions in these 2 regions. We suggest that large differences will be found among native grape phylloxera populations in different geographic regions. An important question is whether populations on different host species within geographic regions genetically distinct. We are currently addressing this question in 2 sympatric Vitis species (V. aestivalis Michaux and V. vulpina L.) in Missouri. 


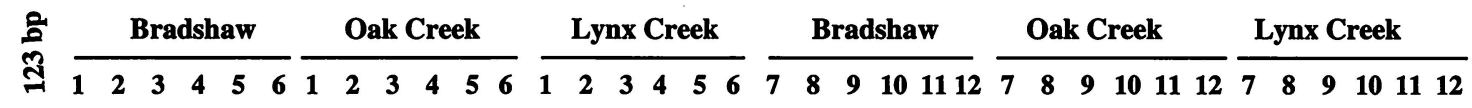

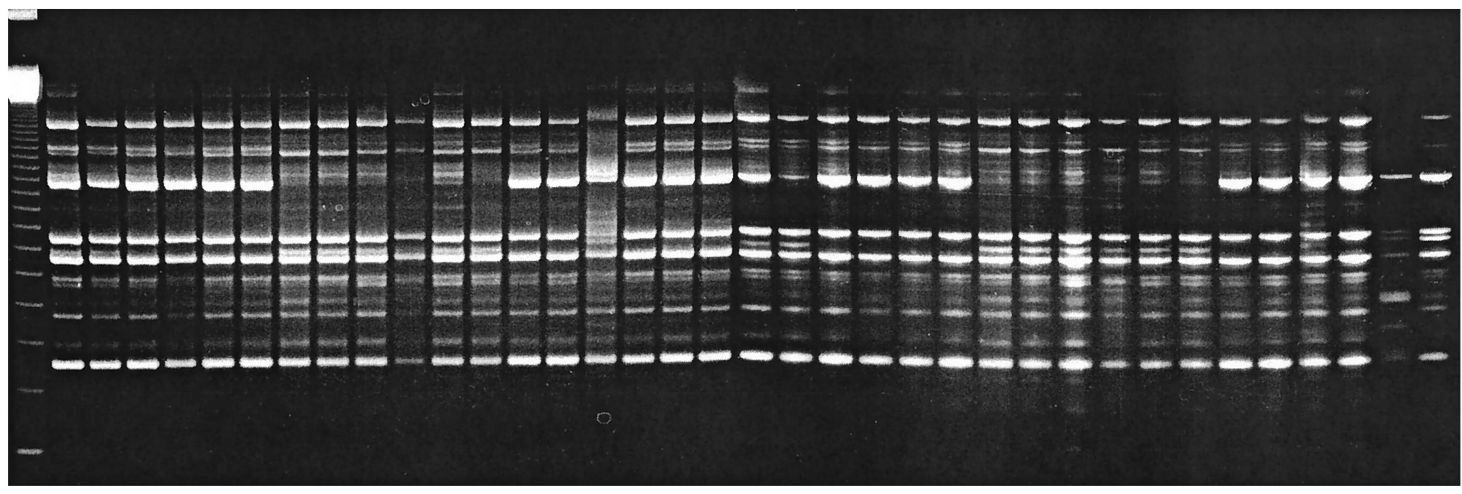

Fig. 2. RAPD results using primer OPG-16 with Arizona phylloxera DNA extracted from 36 samples (4 samples from 3 different V. arizonica vines collected at 3 locations: Bradshaw Mountains, Lynx Creek, and Oak Creek), samples 1, 2, 3, and 4 from vine 1; samples 5, 6, 7, and 8 from vine 2; samples 9, 10, 11, and 12 from vine 3. A 123-bp DNA marker was loaded on the left-hand lane.

A previous survey of genetic diversity in grape phylloxera used RAPD markers to examine 13 clones collected in California vineyards (Fong et al. 1995). This study detected relatively high levels of genetic divergence (up to 25\%) among clones, and the authors speculated that multiple introductions, strong selective pressure from diverse rootstock hosts, abnormally high mutation rates, or an undetected sexual cycle may have been responsible. However, no study of genetic diversity in populations from the native range of phylloxera existed for comparison. The results of the current study, from presumably long-standing populations, suggest that the extent of genetic divergence observed in the study by Fong et al. (1995) is unlikely to have arisen in situ, but probably already existed among multiple founders that were introduced into California from widely separated locations. This pattern has been documented in aphids as well (Mosco et al. 1997, Porter et al. 1997). This conclusion presents important information for how resistant rootstocks are deployed and how biotypic variation is interpreted.

Four features of grape phylloxera biology have emerged from this study, as follows: (1) clonal reproduction in grape phylloxera has now been experimentally demonstrated; (2) individual vines are not dominated by single clones (i.e., genetic differences exist among individuals in close proximity; (3) little genetic structure exists among individual vines as might be expected in a sedentary herbivore on a long-lived host. This could be caused by movement of crawlers and alates as well as through the dynamics of transient
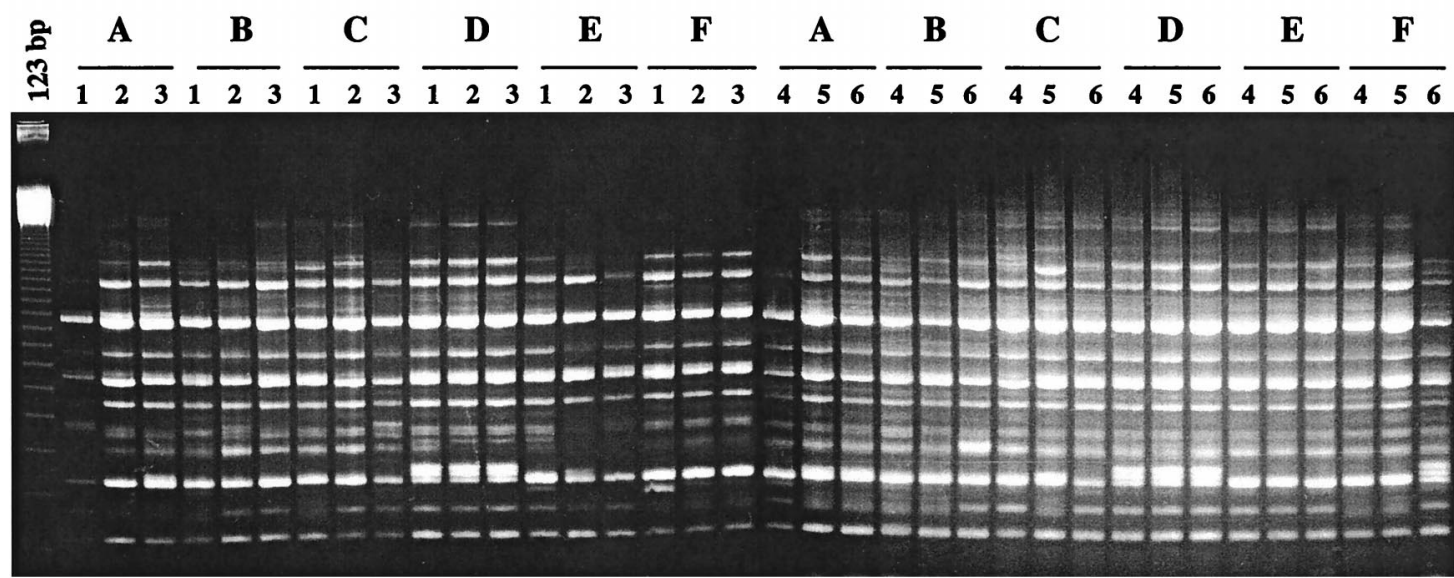

Fig. 3. RAPD results using primer OPG-16 with New York phylloxera DNA extracted from 36 samples. Six samples from 6 V. riparia vines, labeled A through $\mathrm{F}$, collected over a 14-km transect (see text). A 123-bp DNA marker was loaded on the left-hand lane. 
infestations; and (4) relatively small geographic disjunctions $(20-80 \mathrm{~km})$ can produce significant genetic divergence.

The results presented here promote further study of genetic diversity among native and cultivated vineyard phylloxera populations with sampling structures that will allow direct comparisons. Future studies will focus on the extent and causes of genetic divergence among grape phylloxera populations, how genetic diversity is maintained in nature, and whether situations exist in vineyards that might promote adaptive changes in feeding behavior and fitness. Answers to these questions will help grape rootstock breeding programs and allow better pest control strategies.

\section{Acknowledgments}

We thank Daniel Ng for technical assistance. The financial support of a Specific Cooperative Agreement with the USDA-ARS, Fresno Station; the American Vineyard Foundation; and the California Grape Rootstock Improvement Commission is gratefully acknowledged.

\section{References Cited}

Black, W. C., N. M. DuTean, G. J. Puterka, J. R. Nechols, and J. M. Pettorini. 1992. Use of the random amplified polymorphic DNA polymerase chain reaction to detect DNA polymorphism in aphids. Bull. Entomol. Res. 82: 151-159.

Cenis, J. L., P. Perez, and A. Fereres. 1993. Identification of aphid species and clones by random amplified polymorphic DNA. Ann. Entomol. Soc. Am. 86: 545-550.

Davidson, W. M., and R. L. Nougaret. 1921. The grape phylloxera in California. U.S. Dep. Agric. Bull. 903.

De Benedictis, J. A., J. Granett, and S. P. Taormino. 1996. Differences in host utilization by California strains of grape phylloxera. Am. J. Enol. Vitic. 47: 1-7.

Downie, D. A., and J. Granett. 1998. A life cycle variation in grape phylloxera Daktulosphaira vitifoliae Fitch. Southwest. Entomol. 23: 11-16.

Edmunds, G. F., and D. N. Alstad. 1978. Coevolution in insect herbivores and conifers. Science (Wash. D.C.) 199: 941-945.

Excoffier, L., P. E. Smouse, and J. Quattro. 1992. Analysis of molecular variance from metric distance among DNA haplotypes: application to human mitochondrial DNA restriction data. Genetics 131: 479-491.
Fong, G., M. A. Walker, and J. Granett. 1995. RAPD assessment of California phylloxera diversity. Mol. Ecol. 4: 459464.

Granett, J., P. Timper, and L. A. Lider. 1985. Grape phylloxera biotypes in California. J. Econ. Entomol. 78: 14631467.

Hawthorne, D. J., and T. J. Dennehy. 1991. Reciprocal movement of grape phylloxera (Homoptera, Phylloxeridae) alates and crawlers between 2 differentially phylloxera-resistant grape cultivars. J. Econ. Entomol. 84: $230-236$.

Huff, D. R., R. Peakall, and P. E. Smouse. 1993. RAPD variation within and among natural populations of outcrossing buffalograss [Buchloe dactyloides (Nutt.) Engelm.]. Theor. Appl. Genet. 86: 927-934.

Kambhampati, S., W. C. Black, and K. S. Rai. 1992. Random amplified polymorphic DNA of mosquito species and populations (Diptera: Culicidae): techniques, statistical analysis, and applications. J. Med. Entomol. 29: 939-945.

Lin, H., and M. A. Walker. 1996. Preparation of DNA from a single egg of grape phylloxera (Daktulosphaira vitifoliae Fitch) for use in RAPD testing. Vitis 35: 87-89.

Mosco, M. C., P. Arduino, L. Bullini, and S. Barbagallo. 1997. Genetic heterogeneity, reproductive isolation, and host preferences in mealy aphids of the Hyalopterus pruni complex. Mol. Ecol. 6: 667-670.

Nei, M. 1987. Molecular evolutionary genetics. Columbia University Press, New York.

Nolan, M. F., M. L. Skootnicki, and A. J. Gibbs. 1996. RAPD variation in populations of Cardamine lilacina (Brassicaceae). Aust. Sys. Bot. 29: 291-299.

Porter, D. R., J. D. Burd, K. A. Shufran, J. A. Webster, and G. L. Teetes. 1997. Greenbug biotypes: selected by resistant cultivars or preadapted opportunists? J. Econ. Entomol. 90: 1055-1065.

Rui, L., and R. H. Gerald. 1996. Use of RAPD analysis to estimate population genetic parameters in the alfalfa leafcutting bee, Megachile rotundata. Genome 39: 655-663.

Sneath, P.H.A., and R. R. Sokal. 1973. Numerical taxonomy. Freeman, San Francisco.

Williams, J.G.K., A. R. Kubelik, K. J. Livak, J. A. Rafalski, and S. V. Tingey. 1990. DNA polymorphisms amplified by arbitrary primers are useful as genetic markers. Nucleic Acids Res. 18: 6531-6535.

Received for publication 29 May 1998; accepted 18 December 1998. 